\title{
PELAKSANAAN ITSBAT NIKAH PASCA BERLAKUNYA UU NO. 1 TAHUN 1974 TENTANG PERKAWINAN DI PENGADILAN AGAMA
}

\author{
Edi Gunawan \\ Fakultas Syariah IAIN Manado \\ Jl. DR. S.H. Sarundajang Kawasan Ringroad I Manado \\ E-mail: edigunawan@iain-manado.ac.id \\ Budi Rahmat Hakim \\ Fakultas Syariah UIN Antasari Banjarmasin \\ Jl. A.Yani. K.M 4,5 Banjarmasin \\ E-mail: budi_rh@uin-antasari.ac.id
}

\begin{abstract}
Abstrak: Itsbat nikah merupakan sebuah proses penetapan pengesahan pernikahan yang telah dilangsungkan berdasarkan syariat Islam, namun tidak dicatat di KUA. Tujuan dari itsbat nikah adalah untuk mendapatkan akta nikah sebagai bukti sahnya perkawinan sesuai dengan peraturan perundang-undangan yang berlaku di Indonesia, sebagaimana diatur dalam pasal 2 ayat (1) dan (2) UU No. 1 Tahun 1974 dan pasal 7 ayat (1), (2), dan (3) Kompilasi Hukum Islam. Prosedur pengajuan itsbat nikah di Pengadilan Agama Manado setelah berlakunya Undang-Undang Nomor 1 Tahun 1974 yaitu, melakukan pendaftaran ke Pengadilan Agama Manado, membayar panjar biaya perkara, menunggu panggilan sidang dari pengadilan, serta menghadiri persidangan dan putusan pengadilan. Ada beberapa yang menjadi alasan pengajuan itsbat nikah di Pengadilan Agama Manado, antara lain; (1) kehilangan akta nikah, (2) pengurusan perceraian, (3) Perkawinan yang dilangsungkan sebelum berlakunya UU No. 1 Tahun 1974, dan (4) perkawinan yang dilakukan oleh mereka yang tidak mempunyai halangan perkawinan menurut Undang-Undang No. 1 Tahun 1974. Perkara itsbat nikah (pengesahan nikah) bisa diajukan secara voluntair (permohonan) dan diajukan secara kontentius (gugatan) ke pengadilan agama. Dasar pertimbangan hakim dalam memberikan penetapan itsbat nikah di Pengadilan Agama Manado diantaranya yaitu: 1) Legal standing (kedudukan hukum) pemohon untuk mengajukan perkara itsbat nikah di pengadilan agama berdasarkan ketentuan pasal 7 ayat (4) KHI, 2) Posita (fakta kejadian dan fakta hukum), 3) Keterangan saksi dan bukti di persidangan, serta 4) Alasan-alasan mengajukan itsbat nikah.
\end{abstract}

Kata Kunci: Perkawinan, Itsbat Nikah, Voluntair, Pengadilan Agama

Abstract: Itsbat of marriage is an endorsement of the assignment process, which has been held on the basis of Islamic jurisprudence, but not recorded at KUA. The goal of itsbat is to get a marriage license deed as evidence of legitimate marriage in accordance with the legislation in force in Indonesia, as provided for in article 2 paragraph (1) and (2) of law No. 1 of the year 1974 and article 7 paragraph (1), (2) and (3) Compilation Of Islamic Law. Itsbat procedure for making marriage a religious Court in Manado, after the enactment of law number 1 year of 1974, namely, registration to court Religious bias, pay fees, waiting for the call from the Court of session, as well as attend the trial and the verdict of the Court. There are some who became the reason of filing itsbat of marriage in a religious Court in Manado, among others; (1) the lost deed, (2) management, (3) the marriage took 

place before the enactment of law No. 1 year 1974, and (4) a marriage conducted by those who have no impediments to marriage according to the law No. 1 year 1974. Itsbat matter of marriage (endorsement of marriage) may be filed in voluntair (the petition) and filed in kontentius (the suit) to the Court. Basic consideration of judges in giving the setting of itsbat marriage in a religious Court in Manado of which namely: 1) Legal standing (legal position) the applicant to litigate itsbat marriage in a religious court based on the provisions of article 7 paragraph (4) KHI, 2) Posita (facts and legal facts of the incident), 3) witnesses and evidence in the trial, as well as 4) the reasons for filing the itsbat marriage.

Key Words: Marriage, Itsbat, Voluntair, Religious Courts

\section{Pendahuluan}

Perkawinan itu dianggap sah apabila pelaksanaannya sesuai dengan apa telah ditentukan oleh Alquran dan Sunnah Nabi. Tujuan perkawinan adalah untuk membina ketentraman hidup berkeluarga bagi dua orang yang melakukan perbuatan hukum itu untuk memperoleh kebahagiaan, menurunkan keturunan yang sehat dan kuat serta untuk memperbanyak keluarga. Kerabat harus terpelihara dengan baik agar tercipta kerukunan, kasih sayang, tolong menolong dan saling mencintai.

Pasal 1 Undang-undang No.1 Tahun 1974 tentang perkawinan menyebutkan bahwa perkawinan ialah ikatan lahir batin antara seorang pria dengan seorang wanita sebagai suami istri dengan tujuan membentuk keluarga (rumah tangga yang bahagia dan kekal berdasarkan Ketuhanan
Yang Maha Esa) ${ }^{1}$. Sedangkan dalam pasal 2 Kompilasi Hukum Islam disebutkan bahwa perkawinan menurut hukum Islam adalah pernikahan, yaitu akad yang sangat kuat atau mitsaaqan gholiidhan untuk mentaati perintah Allah dan melaksanakannya adalah ibadah.

Dewasa ini, statistik kejadian pernikahan siri meningkat seiring beredarnya berbagai pemberitaan di seluruh jenis media, baik media audio, visual, maupun audiovisual akan pernikahan siri yang dilakukan oleh beberapa selebritis dan pejabat publik, dengan pemberitaan tinggi menyebabkan proses adaptasi yang dilakukan masyarakat akan berbagai budaya baru yang terjadi. Namun akibat pemberitaan yang berulangulang, budaya tersebut semakin cepat diterima oleh masyarakat dan dijadikan bagian dari budaya masyarakat itu

${ }^{1}$ UU No.1 Tahun 1974 tentang 
sendiri, terlebih lagi selebritis dan pejabat publik adalah publik figur yang secara umum selalu ditiru tingkah lakunya oleh masyarakat.

Salah satu pengertian dari pernikahan siri adalah pernikahan yang sah secara agama, yaitu pernikahan yang terpenuhi syarat-syarat dan rukun pernikahan, akan tetapi tidak dicatatkan pernikahannya pada lembaga pencatatan nikah yaitu Kantor Urusan Agama (KUA) bagi umat Islam. Ada beberapa faktor sehingg pernikahan tersebut tidak dicatatkan dan Kantor Urusan Agama, antara lain, faktor biaya atau pelaku pernikahan tidak mampu membayar biaya administrasi pernikahan. Adapula yang takut ketahuan melanggar aturan melarang Pegawai Negeri Sipil untuk menikah lebih dari satu istri, dan lain sebagainya.

Menurut hukum Islam, suatu perkawinan dinyatakan sah kalau perkawinan tersebut memenuhi rukun dan syarat perkawinan serta tidak ada larangan perkawinan di antara mereka yang akan melaksanakan perkawinan tersebut. Rukun dan syarat perkawinan serta larangan-larangan dalam perkawinan telah diatur dalam hukum
Islam (fiqh munakahat) sebagaimana tertuang dalam Buku I Kompilasi Hukum Islam di Indonesia (sebagai himpunan hukum Islam hasil kesepakatan ulama Indonesia) sebagai berikut :

1. Rukun dan syarat perkawinan diatur dalam Bab IV pasal 14 s.d pasal 29.

2. Larangan perkawinan diatur dalam Bab VI Pasal 39 s.d Pasal 44.

Dengan mencermati jalan perkara berbagai kasus yang pernah diangkat dalam beberapa tulisan, terutama kasus yang berkaitan dengan masalah pernikahan siri, dapat ditarik kesimpulan bahwa betapa pentingnya sosialisasi hukum Islam kepada masyarakat yang bukan saja bentuk rumusan hukum normatif, tetapi juga terutama tentang aspek tujuan hukum yang dalam kajian hukum Islam dikenal dengan maqasyid asy-syariah. Secara teoritis, hukum Islam dirumuskan oleh perumusnya (Allah swt) secara umum tidak lain bertujuan untuk meraih kemaslahatan dan menghindarkan kemudharatan ${ }^{2}$.

\footnotetext{
${ }^{2}$ Satria Efendi M. Zein, Problematika Hukum Keluarga Islam Kontemporer, Analisis dengan Pendekatan Ushuliyah (Cet. I; Jakarta: Prenada Media, 2004), h. 29.
} 
Kontroversi tentang pemahaman ketentuan pasal 2 ayat (2) Undangundang Nomor 1 Tahun 1974 tentang pencatatan perkawinan sebagai salah satu sahnya perkawinan akan terus berlanjut, oleh karena itu banyak pula masyarakat yang tidak memandang perlu perkawinannya dicatatkan karena pencatatan bukan merupakan syarat sahnya perkawinan.

Dalam penjelasan Pasal 2 ayat (2) menyebutkan "Pencatatan tiap-tiap perkawinan adalah sama halnya dengan pencatatan peristiwa-peristiwa penting dalam kehidupan seseorang, misalnya kelahiran dan kematian". pencatatan kelahiran, pencatatan kematian, demikian pula pencatatan perkawinan sekedar dipandang sebagai suatu peristiwa penting bukan suatu peristwa hukum. Pesta perkawinan juga peristiwa penting tapi bukan peristiwa hukum, oleh karena itu syarat sahnya perkawinan sebagai peristiwa hukum ditentukan oleh terpenuhinya syarat menurut agama, bukan oleh syarat pencatatan.

Boleh jadi maraknya peristiwa perkawinan yang tidak tercatat akibat adanya pemahaman dan anggapan pencatatan bukan merupakan peristiwa hukum sehingga perkawinan cukup dilaksanakan menurut ketentuan agama, mereka tidak memperhitungkan akibat hukum dari tidak tercatatnya pernikahan tersebut dikemudian hari. Ketika status perkawinannya bersinggungan dengan hak-hak keperdataan yang lain, banyak diantara mereka menempuh cara dengan mengajukan perkara itsbat nikah di Pengadilan Agama.

Untuk memberikan legitimasi nikah siri atau perkawinan yang tidak dicatatkan, maka ditempuh dengan permohonan itsbat nikah ke Pengadilan Agama. Itsbat nikah yang sering disebut dengan pengesahan nikah adalah kewenangan Pengadilan Agama yang merupakan perkara voluntair. Perkara voluntair adalah perkara permohonan yang hanya terdiri dari pemohon saja. Oleh karena itu, perkara voluntair tidak disebut sebagai perkara karena tidak ada pihak lawan atau tidak ada obyek hukum yang disengketakan ${ }^{3}$.

${ }^{3}$ http:/ / badilag.net/artikel/12647nikah-sirri-vs-itsbat-nikah-oleh-drs-h-abd-rasyidasad-mh-259.html_, diakses pada tanggal 25 Februari 2017. 
Pengesahan Nikah/Itsbat Nikah diatur dalam pasal 2 ayat (5) Undangundang Nomor 2 Tahun 1946. Pasal 49 angka (22) Penjelasan Undang-undang No.7 Tahun 1989 sebagaimana telah diubah dengan Undang-undang No.3 Tahun 2006 dan perubahan kedua dengan Undang-undang No.50 Tahun 2009, dan pasal 7 ayat (2), (3) dan (4) Kompilasi Hukum Islam. Menurut ketentuan pasal 7 ayat (3) KHI tersebut, Itsbat Nikah yang dapat diajukan ke Pengadilan Agama terbatas mengenai hal-hal yang berkaitan dengan:

(a). Adanya pekawinan dalam rangka penyelesaian perceraian;

(b). Hilangnya Akta Nikah;

(c). Adanya keraguan tentang sah tidaknya salah satu syarat perkawinan;

(d). Adanya perkawinan yang terjadi sebelum berlakunya Undangundang No. 1 Tahun 1974 dan;

(e). Perkawinan yang dilakukan oleh mereka yang tidak mempunyai halangan perkawinan menurut Undang-undang No.1 Tahun 19744 .

${ }^{4}$ Abdurrahman, Kompilasi Hukum Islam di Indonesia (Cet.III; Jakarta: Akademi Pressindo, 2001), h. 115.
Dari ketentuan pasal tersebut telah dapat dipahami perkara Itsbat Nikah bagi perkawinan yang tidak dicatat yang dapat diajukan ke Pengadilan Agama, hanyalah perkawinan yang dilangsungkan sebelum berlakunya secara efektif Undang-undang No.1 Tahun 1974, kecuali ketentuan dalam huruf (a) yang memberi kesempatan perceraian bagi perkawinan tidak tercatat yang dilangsungkan sebelum atau sesudah berlakunya Undang-undang No.1 Tahun 1974. sebagaimana juga yang telah dinyatakan dalam buku pedoman pelaksanaan tugas dan administrasi peradilan agama (buku II edisi revisi 2010) halaman 147.

Dalam Pasal 49 ayat (2) UndangUndang 7 Tahun 1989 tentang Pengadilan Agama yang telah dirubah dengan Undang-Undang No. 3 Tahun 2006 dan terakhir dengan UndangUndang No. 50 Tahun 2009, kompetensi absolut Pengadilan Agama di antaranya adalah Itsbat Nikah, yaitu pernyataan tentang sahnya perkawinan yang terjadi sebelum Undang-Undang Nomor 1 Tahun 1974 tentang 
Perkawinan dan dijalankan menurut peraturan yang lain.

Landasan yuridis dari itsbat nikah terdapat di dalam Pasal 49 ayat (2) Undang-Undang No. 3 Tahun 2006. Dari ketentuan tersebut, dapat dirumuskan bahwa kompetensi absolut Pengadilan Agama tentang itsbat nikah adalah perkawinan yang terjadi sebelum berlakunya Undang-Undang No. 1 Tahun 1974, bukan perkawinan yang terjadi sesudahnya. Namun, dalam praktiknya, permohonan itsbat nikah yang diajukan ke Pengadilan Agama sekarang ini pada umumnya sekitar 95\% adalah perkawinan yang dilangsungkan pasca berlakunya Undang-Undang No. 1 Tahun 1974 tentang Perkawinan.

\section{Pengertian Itsbat Nikah}

Secara terminologi, itsbat berasal dari bahasa Arab yang mempunyai arti penetapan, sedangkan secara terminologi, itsbat nikah adalah penetapan suatu perkawinan. Itsbat nikah dilakukan karena berbagai sebab yang menyebabkan suatu perkawinan tidak dicatatkan menurut peraturan perundang-undangan yang berlaku.
Kompilasi Hukum Islam tidak mengatur mengenai pengertian itsbat nikah, hanya saja dalam Kompilasi Hukum Islampasal 7 ayat (3), menyebutkan bahwa, "Dalam hal perkawinan tidak dapat dibuktikan dengan Akta Nikah, dapat diajukan itsbat nikahnya ke Pengadilan Agama”. Dari pengertian tersebut dapat dipahami bahwa itsbat nikah adalah permohonan untuk dibuatkannya Akta Nikah agar perkawinannya tersebut dapat dibuktikan.

Salah satu kewenangan absolut pengadilan agama adalah, menerima, memeriksa, mengadili dan menyelesaikan perkara istbat nikah bagi pasangan suami istri yang tidak mempunyai akta nikah. Aturan pengesahan perkawinan/istbat nikah, dibuat atas dasar adanya perkawinan yang dilangsungkan berdasarkan agama atau tidak dicatat oleh Pegawai Pencatat Nikah yang berwenang 5 . Pada awalnya perkawinan hanya disahkan bagi perkawinan yang berlangsung sebelum berlakunya Undang-undang No.1 tahun 1974 tentang perkawinan.

${ }^{5}$ Mahkamah Agung RI, Pedoman Teknis Administrasi dan Pedoman Teknik Peradilan Agama (Buku II Edisi 2009), h. 207 
Akan tetapi pasal 7 Kompilasi Hukum Islam memberikan peluang untuk pengesahan perkawinan yang tidak dicatat oleh PPN yang dilangsungkan sebelum atau sesudah berlakunya Undang-undang No. 1 tahun 1974 tentang perkawinan untuk kepentingan perceraian. Bahkan dalam perkembangannya, bukan hanya untuk kepentingan perceraian, tetapi untuk mengesahkan pernikahan siri dengan istri kedua, ketiga atau bahkan keempat dengan mengajukan itsbat nikah ke Pengadilan Agama.

Berdasarkan pengertian di atas, dapat disimpulkan bahwa itsbat nikah adalah penetapan perkawinan oleh pengadilan agama tentang keabsahan perkawinan suami istri yang perkawinannya tidak dicatatkan dan tidak dapat dibuktikan.

Itsbat Nikah dalam UU No. 1 Tahun 1974 tentang Perkawinan dan Kompilasi Hukum Islam

Seperti diketahui bahwa setiap perbuatan hukum yang dapat dinyatakan sah dan mempunyai akibat hukum adalah apabila perbuatan hukum itu dapat dibuktikan dengan jelas dan pasti. Untuk dapat membuktikan kebenaran adanya perkawinan yang telah terjadi maka dapat dilihat dari alat bukti yang ada. Alat bukti yang ada biasanya adalah berupa alat bukti saksi dan alat bukti tertulis, alat bukti tertulis bagi suatu perkawinan yang berlaku dimasyarakat sebagai hasil dari kewajiban pencatatan perkawinan adalah akta nikah yang dibuat oleh Pegawai Pencatat Perkawinan. Adapun alat bukti saksi dalam suatu perkawinan dapat juga diterima tetapi tidak dapat menjamin kelangsungan pembuktian atas perkawinan. Hal ini dikarenakan saksisaksi tersebut suatu waktu tidak ada yang bisa terjadi karena saksi tersebut meninggal dunia atau hilang atau tidak diketahui keberadaannya. Oleh karena itu alat bukti tertulis sangatlah penting.

Namun ada kalanya perkawinan yang telah terjadi dan telah sesuai dengan ketentuan hukum agama dan telah dianggap sah secara materil menurut hukum agama, tidak dapat dibuktikan kebenaran dari perkawinan tersebut dikarenakan perkawinan tersebut tidak memiliki alat bukti tertulis yang menerangkan telah 
terjadinya suatu perkawinan. Maka yang hanya terdiri dari pemohon saja. dengan tidak ada adanya bukti, maka Oleh karena itu, perkara voluntair tidak kedudukan hukumnya lemah baik disebut sebagai perkara karena tidak untuk si istri maupun kedudukan ada pihak lawan atau tidak ada obyek anaknya dan masyarakat dapat saja hukum yang disengketakan.

menyangkal adanya perkawinan Lembaga

itsbat tersebut. Oleh karena itu, untuk nikah/pengesahan nikah yang termuat mengatasi tidak adanya bukti tertulis dalam UU No. 1 Tahun 1974 hanya maka Pengadilan Agama berusaha terbatas pada ulasan perkawinan yang membantu masyarakat untuk terjadi sebelum UU No. 1 Tahun 1974, memperoleh bukti tertulis yang dapat hal ini dapat dilihat dalam pasal 49 ayat membuktikan dan mensahkan (2) UU No 50 Tahun 2009 tentang perkawinan mereka. Pengesahan Peradilan Agama, yaitu bidang perkawinan Pengadilan Agama adalah perkawinan sebagaimana yang berupa itsbat nikah dan dituangkan dimaksud dalam ayat 1 huruf a, ialah dalam bentuk penetapan pengadilan hal-hal yang diatur dalam atau yang dapat menjadi suatu alat bukti berdasarkan undang-udang mengenai tertulis atas perkawinan ${ }^{6}$.

Untuk memberikan legitimasi perkawinan yang berlaku, sedangkan dalam penjelasan pasal 49 ayat (2) nikah siri atau perkawinan yang tidak dicatatkan, maka ditempuh dengan permohonan itsbat nikah ke pengadilan agama. Itsbat nikah yang sering disebut dengan pengesahan nikah adalah kewenangan pengadilan agama yang merupakan perkara voluntair. Perkara voluntair adalah perkara permohonan

${ }^{6}$ Rizky Amalia, Itsbat nikeah Terhadap Perkawinan yang Dilangsungkan Sebelum dan Sesudah Berlakunya UU No. 1 Tahun 1974 Tentang Perkawinan (Studi Kasus Penetapan PA Jakarta Selatan dan PA Depok) (Tesis, Universitas Indonesia, Jakarta: 2012), h. 46 tersebut dikatakan bahwa salah satu bidang perkawinan yang diatur dalam Undang-undang No. 1 Tahun 1974 adalah "Pernyataan tentang sahnya perkawinan yang terjadi sebelum UU No. 1 Tahun 1974 tentang Perkawinan dijalankan menurut peraturan yang lain."

Dalam Pasal 7 ayat (2) dan ayat (3) Kompilasi Hukum Islam disebutkan bahwa: 
ayat (2). Dalam hal perkawinan tidak atas sulit dipahami, tetapi mayoritas dapat dibuktikan dengan akta nikah, hakim Pengadilan Agama dengan dapat diajukan itsbat nikah ke penafsiran yang kabur memahami pengadilan agama.

ayat (3). Itsbat nikah yang dapat seolah-olah merupakan keharusan diajukan ke pengadilan agama untuk menerima permohonan itsbat terbatas mengenai hal-hal yang nikah jika diajukan dengan dikomulasi berkenaan dengan:

gugatan perceraian, walaupun

a. Adanya perkawinan dalam rangka perkawinan itu dilakukan setelah penyelesaian perkawinan; berlakunnya Undang-Undang No. 1

b. Hilangnya akta nikah;

c. Adanya keraguan tentang sah atau tidaknya salah satu syarat perkawinan ;

Tahun 1974. Demikian juga ketika hakim memahami ketentuan Pasal 7 Ayat (3) huruf e Kompilasi Hukum Islam.

d. Adanya perkawinan yang terjadi

Kedudukan Kompilasi Hukum sebelum berlakunya UndangUndang No. 1 tahun 1974.

Islam jika ditinjau dari hierarki peraturan perundang-undangan seperti

e. Perkawinan yang dilakukan oleh yang diatur dalam Pasal 7 Undangmereka yang tidak mempunyai halangan perkawinan menurut Undang No. 10 Tahun 2004 tentang Undang-Undang No. 1 Tahun 1974.

Dalam praktik beracara di Tata Urutan Perundang-undangan, Kompilasi Hukum Islam (Inpres No. 1 Tahun 1991) tidak termasuk dalam Pengadilan Agama, hakim pada umumnya langsung menerapkan Pasal 7 Ayat (2) dan (3) Kompilasi Hukum Islam (KHI) tanpa menguji kekuatan keberlakukan KHI di hadapan undangundang. Dengan demikian, meskipun ketentuan Pasal 7 Ayat (3) huruf a di hierarki peraturan perundangundangan, dan kedudukannya jauh di bawah undang-undang. Ketentuan Inpres tidak boleh bertentangan dengan undang-undang. Apabila Inpres (KHI) bertentangan dengan undangundang atau ketentuan hukum yang lebih tinggi, maka Inpres tidak dapat 
dijalankan. Hal ini sesuai dengan asas "Lex Superior Dragot lex Inferior" (ketentuan hukum yang lebih tinggi mengenyampingkan hukum di bawahnya).

Terhadap perkawinan yang dilakukan sebelum berlakunya UndangUndang No. 1 Tahun 1974 tentang Perkawinan, jika diajukan permohonan itsbat nikah ke pengadilan agama, hakim yang memeriksa permohonan tersebut, harus cermat meneliti apakah perkawinan yang dimohonkan untuk di-itsbat-kan itu dilaksanakan telah terpenuhi syarat dan rukun nikah sebagaimana yang ditentukan dalam hukum Islam atau tidak. Jika dalam pemeriksaan dipersidangan tidak terbukti bahwa perkawinan itu dilakukan telah sesuai dengan ketentuan hukum Islam, hakim wajib menolak permohonan itsbat nikah itu, walaupun diajukan dalam rangka perceraian. Sebab bagaimana mungkin hakim menyatakan sahnya suatu perkawinan yang tidak memenuhi syarat dan rukun perkawinan. Oleh karena itu, seharusnya ketentuan Pasal 7 ayat (3) huruf (e) KHI tersebut memberi kriteria yang jelas dan tegas, bahwa perkawinan yang dapat dimohonkan itsbat ke pengadilan agama adalah perkawinan yang dilangsungkan sebelum berlakunya Undang-Undang No. 1 Tahun 1974, dan perkawinan yang memenuhi syarat dan rukun perkawinan sesuai dengan ketentuan hukum Islam.

Meskipun masalah pencatatan perkawinan telah tersosialisasikan cukup lama, dalam pasal 2 ayat (2) UU No. 1 Tahun 1974 tentang Perkawinan maupun pasal 5 dan $6 \mathrm{KHI}$, tetapi sampai saat ini masih banyak kendala dihadapi dalam pelaksanaannya. Hal ini karena sebagian masyarakat muslim masih ada yang berpegang teguh kepada perspektif fikih tradisional. Menurut pemahaman mereka perkawinan sudah sah apabila ketentuan-ketentuan yang tersebut dalam kitab-kitab fikih sudah terpenuhi, tidak perlu ada pencatatan di KUA dan tidak perlu surat nikah sebab hal itu tidak diatur pada zaman Rasulullah dan merepotkan saja ${ }^{7}$.

Tampaknya jalur nikah siri akan menjadi pilihan bagi mereka yang

${ }^{7}$ Abdul Manan, Aneka Masalab Hukum Perdata Islam di Indonesia ( Jakarta: Kencana, 2006). h 47. 
bermaksud beristri lebih dari satu Tehnis Peradilan Agama 2008, bahwa orang melalui cara pengesahan nikah perkawinan yang tidak dicatatkan oleh (itsbat nikah), dibandingkan dengan PPN banyak berindikasikan prosedur poligami menurut ketentuan penyelundupan hukum untuk UU perkawinan. Oleh karena itu, perlu mempermudah poligami tanpa dipikirkan dan dikaji secara mendalam prosedur hukum, dan memperoleh sebelum dan atau dalam menetapkan hak-hak waris atau hak-hak lain atas kebijakan penegakan hukum dalam kebendaan. Oleh karena itu, pengadilan memberikan alternatif penyelesaian agama harus berhati-hati dalam permasalahan kebutuhan dan kepastian memeriksa dan memutus permohonan hukum terhadap nikah siri melalui itsbat nikah, agar proses itsbat nikah itsbat nikah. Dalam upaya untuk tidak dijadikan alat untuk melegalkan menghindari tumbuhnya kecenderung- perbuatan penyelundupan hukum. an jatuhnya pada pilihan pengajuan Untuk kepentingan tersebut, maka itsbat nikah yang menjurus pada proses pengajuan, pemeriksaan dan poligami tersebut, menurut Abdul Gani penyelesaian permohonan itsbat nikah Abdullah, hakim perlu mengambil harus mengikuti petunjuk Buku II. sikap:

1. Perlu diperketat syarat berlaku adil;

2. Perlu ditemukan unsur pemberatan akibat dari suatu itsbat nikah;

3. Sebelum dikabulkan suatu perceraian, Perlu dipenuhi seluruh akibat perkawinan dari itsbat nikah yang sebelum putusan perceraian dipertimbangkan untuk dikabulkan ${ }^{8}$. Sebagaimana petunjuk dalam Pedoman Tehnis Administrasi dan

8 Abdul Gani Abdullah, Sekitar masalah pengesahan Nikah Siri (Materi Rakernas Perdata Agama Mahkamah Agung RI, Jakarta, 2008), h.13-14.

\section{Pelaksanaan Itsbat Nikah di \\ Pengadilan Agama Manado}

Pasal 2 UU No. 1 Tahun 1974

tentang Perkawinan menentukan sebagai berikut :

(1) Perkawinan adalab sab, apabila dilakukan menurut bukum masingmasing agamanya dan kepercayaannya $i t u$.

(2) Tiap-tiap perkawinan dicatat menurut peraturan perundang-undangan yang berlaku. 
Dari ketentuan tersebut, ketentuan Pasal 7 ayat (2) Kompilasi diketahui sahnya suatu perkawinan Hukum Islam menyatakan bahwa apabila dilakukan menurut masing- "Dalam hal perkawinan tidak dapat masing agama maupun dibuktikan dengan Akta Nikah, dapat kepercayaannya, namun demikian diajukan itsbat nikahnya ke Pengadilan diatur pula bahwa tiap-tiap perkawinan Agama” dicatat menurut ketentuan perundang- Sesuai dengan ketentuan di atas, undangan yang berlaku. Hal ini selaras itsbat nikah hanya dapat diajukan dengan ketentuan dalam Pasal 7 ayat 1 melalui pengadilan agama, di wilayah Kompilasi Hukum Islam yang tempat tinggal orang yang akan mengatur bahwa "Perkawinan hanya mengajukan itsbat nikah, bukan melalui dapat dibuktikan dengan akta nikah yang Kantor Urusan Agama (KUA). dibuat oleh Pegawai Pencatat Nikah.” Adapun syarat-syarat yang harus

Akta nikah berguna untuk dipenuhi seseorang untuk mengajukan membuktikan adanya perkawinan itsbat nikah di Pengadilan Agama tersebut dan sebagai jaminan bagi Manado adalah sebagai berikut:

suami atau istri serta melindungi hak- 1. Menyerahkan Surat Permohonan hak anak yang lahir dari perkawinan Itsbat Nikah kepada Pengadilan tersebut. Sebagai contoh dalam hal warisan, pengurusan akta kelahiran, dan lain sebagainya. Dengan demikian, suatu perkawinan yang belum atau tidak dilakukan pencatatan di kantor pencatatan perkawinan akan merugikan suami, istri, dan anak.

Pegawai Pencatat Nikah tidak dapat menerbitkan akta nikah atas pernikahan siri. Untuk melakukan Agama setempat;

2. Surat keterangan dari Kantor Urusan Agama (KUA) setempat yang menyatakan bahwa pernikahan tersebut belum dicatatkan;

3. Surat keterangan dari Kepala Desa/Lurah yang menerangkan bahwa pemohon telah menikah;

4. Foto copy KTP pemohon itsbat nikah;

pencatatan atas pernikahan siri, 5. Membayar biaya perkara; sebagaimana yang diatur dalam 
6. Lain-lain yang akan ditentukan hakim dalam persidangan?

Namun, permohonan itsbat nikah tidak selalu dikabulkan oleh hakim, jika permohonan tersebut dikabulkan, maka pengadilan akan mengeluarkan putusan atau penetapan itsbat nikah. Dengan adanya putusan penetapan itsbat nikah, maka secara hukum perkawinan tersebut telah tercatat yang berarti adanya jaminan ataupun perlindungan hukum bagi hakhak suami/istri maupun anak-anak dalam perkawinan tersebut. Setelah perkawinan disahkan menurut agama dan negara, sebagaimana diatur dalam UU Perkawinan dan Kompilasi Hukum Islam, maka dapat mengurus akta kelahiran anak yang sah sesuai dengan prosedur yang berlaku di Kantor Pencatatan Sipil setempat dengan melampirkan surat putusan itsbat nikah yang menunjukkan adanya pernikahan yang sah antara suami dan istri. Sehingga anak nantinya dapat teercatat sebagai anak dari pasangan yang telah menikah secara sah dimata hukum. Adapun prosedur pengajuan

${ }^{9}$ Wawancara dengan Bambang Suroso SH (panitera Muda Hukum), pada tanggal 17 Juli 2013, pukul 10. 00 wita di Pengadilan Agama Manado. permohonan itsbat nikah di Pengadilan Agama Manado adalah;

a. Proses di Luar Pengadilan

1) Pemohon mengajukan permohonan ke Pengadilan Agama.

a) Suami sebagai pemohon pertama

b) Istri sebagai pemohon kedua

2) Pemohon mendaftarkan permohonan Itsbat nikah itu ke Meja I.

3) Di Meja I pemohon akan diberikan surat kuasa untuk membayar (SKUM).

4) Setelah semua berkas diberikan kepada pemohon maka pemohon diwajibkan membayar di kasir biaya yang angkanya tertera di SKUM tersebut.

5) Setelah dilakukan pembayaran maka pemohon akan diberikan nomor perkara sesuai dengan nomor perkara yang masuk.

6) Setelah diberikan nomor urutan maka kuitansi dan berkas permohonan dikembalikan kepada pemohon.

7) Kemudian pemohon menyerahkan berkas yang lengkap dengan kuitansi pembayaran tersebut di Meja II. 
8) Kemudian Meja II akan berkepentingan terhadap perkawinan memberikan semua salinan gugatan tersebut kepada Pengadilan Agama yang di ajukan tersebut.

dalam wilayah hukum pemohon

9) Pemohon diberikan surat kuasa bertempat tinggal, permohonan harus untuk membayar (SKUM) beserta dilengkapi dengan alasan dan salinan dari gugatan atau permohonan $\mathrm{I}^{10}$.

b. Proses di dalam Pengadilan

1) Semua berkas yang di terima kepentingan yang jelas. Bentuk-bentuk pengajuan perkara itsbat nikah telah jelas diuraikan dalam Buku II Edisi kemudian dinaikkan ke Ketua Revisi 2010 pada halaman 148 dan 149 Pengadilan Agama melalui Wakil Panitera dan Panitera.

2. Kemudian Ketua Pengadilan membuat (PMH) Penetapan Majelis Hakim yang menangani perkara tersebut.

3. Kemudian berkas tersebut diserahkan kepada Majelis Hakim yang ditunjuk.

4. Setelah membaca perkara tersebut Majelis Hakim menetapkan hari Sidang (PHS) dengan memerintahkan Juru Sita untuk memanggil para pihak untuk menghadiri Sidang.

Pengajuan permohonan itsbat nikah dapat diajukan oleh kedua suami istri atau salah satu dari istri, anak, wali nikah dan pihak lain yang

${ }^{10}$ Wawancara dengan Bambang Suroso SH ( Panitera Muda Hukum), pada tanggal 17 Juli 2013 pukul 10.00 wita di Pengadilan Agama Manado

alternatif dilihat dari pihak-pihak yang berkepentingan dan terlibat dalam proses perkara Itsbat sebagai berikut:

1) Permohonan itsbat nikah dapat dilakukan oleh kedua suami istri atau salah satu dari suami istri, anak, wali nikah dan pihak lain yang berkepentingan dengan perkawinan tersebut kepada Pengadilan Agama dan Mahkamah Syar'iyah dalam wilayah hukum pemohon bertempat tinggal, dan permohonan Itsbat Nikah harus dilengkapi dengan alasan dan kepentingan yang jelas dan konkrit.

2) Proses permohonan itsbat nikah yang diajukan oleh kedua suami istri bersifat voluntair, produknya berupa penetapan. Jika isi penetapan tersebut menolak permohonan 
itsbat nikah, maka suami dan istri bersama-sama atau suami dan istri masing-masing dapat mengajukan upaya hukum kasasi.

3) Proses pemeriksaan permohonan itsbat nikah yang diajukan oleh salah seorang suami atau istri bersifat kontensius dengan mendudukkan istri atau suami yang tidak mengajukan permohonan sebagai pihak termohon, produknya berupa putusan dan terhadap putusan tersebut dapat diajukan upaya hukum banding dan kasasi.

4) Apabila dalam proses pemeriksaan permohonan itsbat nikah dalam angka (2) dan (3) tersebut diatas diketahui bahwa suaminya masih terikat dalam perkawinan yang sah dengan perempuan lain, maka istri terdahulu tersebut harus dijadikan pihak dalam perkara. Jika pemohon tidak mau merubah permohonannya dengan mamasukkan istri terdahulu sebagai pihak, permohonan tersebut harus dinyatakan tidak dapat diterima.

5) Permohonan itsbat nikah yang dilakukan oleh anak, wali nikah dan pihak lain yang berkepentingan harus bersifat kontensius dengan mendudukkan suami dan istri dan/atau ahli waris lain sebagai termohon;

6) Suami atau istri yang telah ditinggal mati oleh istri atau suaminya, dapat mengajukan permohonan itsbat nikah secara kontensius dengan mendudukkan ahli waris lainnya sebagai pihak termohon, produknya berupa putusan dan atas putusan tersebut dapat diupayakan banding dan kasasi.

7) Dalam hal suami atau istri yang ditinggal mati tidak mengetahui ada ahli waris lain selain dirinya, maka permohonan itsbat nikah diajukan secara voluntair, produknya berupa penetapan. Apabila permohonan tersebut ditolak maka pemohon dapat mengajukan upaya hukum kasasi.

8) Orang lain yang mempunyai kepentingan dan tidak menjadi pihak dalam perkara permohonan itsbat nikah tersbut dalam angka (2) dan (6), dapat melakukan perlawanan kepada Pengadilan Agama atau Mahkamah Syar'iyah 
yang memutus setelah mengetahui ada penetapan itsbat nikah.

9) Orang lain yang mempunyai kepentingan dan tidak menjadi pihak dalam perkara permohonan itsbat nikah tersebut dalam angka (3), (4) dan (5), dapat mengajukan intervensi kepada Pengadilan Agama atau Mahkamah Syar'iyah yang memeriksa perkara itsbat nikah tersebut selama perkara belum diputus.

10) Pihak lain yang mempunyai kepentingan hukum dan tidak menjadi pihak dalam perkara permohonan itsbat nikah tersebut dalam angka (3), (4) dan (5), sedangkan permohonan tersebut telah diputus oleh Pengadilan Agama atau Mahkamah syar'iyah, dapat mengajukan gugatan pembatalan perkawinan yang telah disahkan oleh Pengadilan Agama atau Mahkamah Syar'iyah tersebut ${ }^{11}$.

Contoh kasus perkara itsbat nikah di Pengadilan Agama sebagai berikut:

Perkara Nomor: 78/pdt.G/2013/ PA.Mdo

${ }^{11}$ Mahkamah Agung RI, Pedoman Teknis Administrasi dan Pedoman Teknik Peradilan Agama (Buku II Edisi 2009), h. 148-149.
Seorang istri (A) mengajukan permohonan itsbat nikah kepada Pengadilan Agama yang terdaftar dengan nomor: 78/pdt. G/2013/PA. Mdo, melawan C, D, E, dan F yang semuanya merupakan anak kandung sendiri.

Berdasarkan permohonan pemohon tertanggal 23 Maret 2013, mengajukan dalil-dalil perkara sebagai berikut:

1. Pada tanggal 8 November 1972, pemohon telah melangsungkan pernikahan menurut agama Islam dengan B (almarhum), namun akta nikah mereka hilang pada saat banjir di bulan Februari 2013

2. Pada saat berlangsung pernikahan, yang bertindak sebagai wali adalah ayah kandung pemohon sendiri, dan kedua saksi yang pada saat ini semua telah meninggal.

3. Dari pernikahan mereka telah dikaruniai empat orang anak

4. Suami pemohon adalah seorang pensiunan PNS, dan pernikahan pemohon tidak terjadi perceraian

5. Pemohon membutuhkan penetapan pengesahan pernikahan dengan almarhum suami pemohon untuk 
melengkapi persyaratan pengurusan pensiun janda di PT. Taspen.

Berdasarkan dalil-dalil diatas, dan hasil pemeriksaan di persidangan, melalui pemeriksaan berkas-berkas perkara dan keterangan para saksisaksi, maka hakim mengabulkan permohonan tersebut, dan menetapkan pernikahan yang terjadi antara $\mathrm{A}$ dan $\mathrm{B}$ yang dilaksanakan pada tanggal 8 November 1972 adalah sah secara hukum.

\section{Pertimbangan Hakim dalam}

Mengabulkan Permohonan Itsbat Nikah

Munculnya berbagai macam kasus, seperti suami ingin menceraikan istri yang dinikahi secara siri, lalu mengajukan permohonan talak ke pengadilan agama, maka jalan yang ditempuh harus mengitsbatkan dulu pernikahan sirinya tersebut, disebut itsbat untuk cerai, maka implikasi hukum yang muncul adalah kalau nikah sirinya diitsbatkan walaupun untuk cerai, maka pada saat nikah itu diitsbatkan, maka otomatis muncul hak keperdataan istri, karena telah menjadi istri yang sah memiliki hak-hak seperti seorang istri sah ${ }^{12}$.

Dalam perspektif global seperti uraian di atas, bahwa dengan adanya itsbat nikah, seakan-akan membuka peluang untuk berkembangnya praktek nikah siri, karena kalau ingin mensahkan perkawinannya tinggal ke pengadilan agama mengajukan permohonan itsbat nikah, akhirnya status pernikahannya pun menjadi sah dimata Negara. Sehingga harus dipikirkan bagi hakim apakah dengan mengitsbatkan nikah tersebut akan membawa lebih banyak kebaikan atau justru mendatangkan mudharat bagi semua pihak dalam keluarga tersebut, hal ini tidak boleh luput dari pertimbangan hakim dalam mengabulkan atau menolak permohnan itsbat nikah yang diajukan kepadanya ${ }^{13}$.

Namun demikian sikap hakim dalam mengambil suatu keputusan bersifat bebas dengan pertimbangan dan menafsirkan pasal peratuan perundangan demi kemaslahatan dan

\footnotetext{
${ }^{12}$ Muhsin , Problematika Perkawinan tidak tercatat dalam pandangan Hukum Islam dan Hukum Positif (Materi Rakernas Perdata Agama) h. 21.

${ }^{13}$ Muhsin , Problematika Perkawinan tidak tercatat dalam pandangan Hukum Islam dan Hukum Positif (Materi Rakernas Perdata Agama) h. 21.
} 
keadilan bagi masyarakat. Seperti penafsiran pasal 6 ayat (1) KHI menyatakan bahwa setiap perkawinan harus dilangsungkan dihadapan dan di bawah pengawasan PPN, dan pada ayat (2) disebutkan bahwa perkawinan yang dilangsungkan di luar pengawasan PPN tidak mempunyai kekuatan hukum. Tidak mempunyai kekuatan hukum atau kelemahan hukum tidak berarti bahwa hal itu sebagai suatu perkawinan yang tidak sah atau batal demi hukum.

Pemikiran ini didasari pada pemahaman terhadap UU No.1 Tahun 1974 tentang Perkawinan jo. PP. No.9 Tahun 1975 tentang Pelaksanaan UU No. 1 Tahun 1974 dan KHI, dengan interpretasi bahwa yang menjadi patokan keabsahan suatu perkawinan itu adalah dilaksanakan berdasarkan hukum agama (Islam). Ada dua pandangan mengenai status pencatatan perkawinan tersebut:

(1). Pandangan yang menyatakan bahwa pencatatan perkawinan hanya merupakan

persyaratan administratif, bukan merupakan persyaratan sahnya perkawinan, jadi pencatatan perkawinan hanya proses untuk mendapatkan suatu bukti, bahwa telah terjadi perkawinan. Menurut pendapat ini, sahnya suatu perkawinan hanya didasarkan pada ketentuan agama yang dipeluk oleh orang yang melangsungkan perkawinan, sebagaimana disebutkan pasal 2 ayat (1) Undang-Undang Nomor 1 Tahun 1974 tentang Perkawinan. Pencatatan perkawinan hanya bersifat administratif dan berada di luar unsur keabsahan perkawinan tersebut. Saat mulai sahnya suatu perkawinan adalah sesaat setelah terjadinya ijab qobul antara wali nikah dengan calon pengantin pria. (2). Pandangan yang menyatakan bahwa pencatatan perkawinan menjadi syarat sah perkawinan.

Hasil seminar sehari "Hukum keluarga Nasional antara Realitas dan Kepastian Hukum" yang telah diulas pada sampul belakang majalah Hukum Varia Peradilan No. 286 edisi September 2009 sebagai berikut:

"Fenomena perkawinan tidak tercatat yang biasa disebut "kawin siri" dalam kehidupan masyarakat Indonesia, adalah realita, alasannya mulai dari 
mahalnya biaya pencatatan nikah sampai karena alasan personal yang harus dirahasiakan. Menyikapi persoalan ini, pada tanggal 1 Agustus 2009 di hotel Red Top Jakarta, diadakan Seminal sehari yang diselenggarakan oleh Pusat Pengkajian Hukum Islam dan Masyarakat Madani (PPHIMM), dan diperoleh pernyataan para pakar hukum yang amat mengejutkan diantaranya pernyataan:

1. Prof. DR.Bagir Manan, SH, yang menyimpulkan bahwa: "pencatatan perkawinan adalah suatu yang penting saja untuk dilakukan, oleh karena itu tidak mengurangi keabsahan perkawinan itu sendiri”.

2. Prof.DR.Mahfud MD, SH, yang menyatakan bahwa "perkawinan siri tidak melanggar konstitusi, karena dijalankan berdasarkan akidah agama yang dilindungi UndangUndang Dasar 1945.

3. DR.H.Harifin A, Tumpa,SH; MH. Berpandangan bahwa "kalau perkawinan yang tidak dicatatkan merupakan gejala umum dan didasarkan atas itikad baik atau ada faktor darurat, maka hakim harus mempertimbangkan"14.

Jika pandangan para pakar hukum tersebut dikorelasikan dengan pandangan Prof. DR.H. Muchsin, SH, dalam tulisan beliau berjudul "Problematika Perkawinan tidak tercatat dalam pandangan Hukum Islam dan Hukum Positif (Materi Rakernas Perdata Agama h. 17-18), dengan memandang sejarah hukum dan filosofi hukum dan tujuan pelaksanaan perkawinan dicatatkan, maka akan menjadikan hakim lebih berhati-hati dalam menangani perkara itsbat nikah terutama dalam perkawinan secara poligami.

Apabila perkawinan di bawah tangan sudah menjadi tradisi dalam arti dipatuhi oleh masyarakat, mengikat (pasti akan disahkan atau diitsbatkan juga oleh pengadilan agama), dan dipertahankan secara terus menerus, maka akan terjadi keadaan sebagai berikut ${ }^{15}$ :

${ }^{14}$ H.Andi syamsu Alam (Tuada Uldilag), Beberapa permasalahan Hukum di Lingkungan Uldilag (Hasil Rapat Kerja Nasional Mahkamah Agung RI, tahun 2009), h. 6-7.

${ }^{15}$ Nasrudin Salim, Itsbat nikab dalam Kompilasi Hukum Islam (Mimbar Hukum No. 62 tahun 2003 Edisi September-Oktober). h.72. 
1. Makna historis Undang-Undang Perkawinan akan tidak efektif, sehingga tujuan lahirnya Undangundang tersebut tidak tercapai, dengan demikian pengorbanan bangsa (umat Islam) untuk lahirnya Undang-Undang ini menjadi terabaikan;

2. Tujuan Normatif dari pencatatan perkawinan tidak terpenuhi seperti yang dikehendaki Pasal 2 Undangundang Perkawinan, maka akan menciptakan suatu kondisi ketidak teraturan dalam pencatatan kependudukan;

3. Masyarakat muslim dipandang tidak lagi memperdulikan kehidupan bangsa dan kenegaraan dalam bidang hukum, yang pada akhirnya sampai pada anggapan bahwa pelaksanaan ajaran Islam tidak membutuhkan keterlibatan Negara, yang pada akhirnya mengusung pandangan bahwa agama harus dipisahkan dari kehidupan kenegaraan.

4. Akan mudah dijumpai perkawinan di bawah tangan, yang hanya peduli pada unsur agama saja dibanding unsur tata cara pencatatan perkawinan, yang mungkin akan dikemas dengan berbagai perjanjian perkawinan, antara lain bahwa unsur pencatatan resmi ke Kantor Urusan Agama akan dipenuhi pada waktu yang akan datang dengan tanpa adanya suatu kepastian, yang mengundang ketidakpastian nasib wanita (istri) yang menurut amanat Undang-undang Perkawinan semestinya diprioritaskan untuk dilindungi.

5. Apabila terjadi wanprestasi terhadap perjanjian perkawinan seperti tersebut, maka peluang untuk putusnya perkawinan akan terbuka secara bebas tanpa terlibat prosedur hukum sebagai akibat langsung dari diabaikannya pencatatan oleh Negara, sehingga perkawinan di bawah tangan ini hanya diikuti dengan perceraian di bawah tangan, maka untuk suasana seperti ini adalah sama seperti masa Tahkim dan Muhakkam dalam sejarah masyarakat Islam Indonesia pada masa yang lalu lewat Pengadilan Agama, dengan demikian akan memutus konsistensi dan konsekwensi logis formalisasi 
hukum Islam dalam kehidupan kenegaraan;

6. Akan membentuk preseden buruk sehingga orang akan cenderung menjadi bersikap enteng untuk mengabaikan pencatatan nikahnya secara langsung pada saat sebelum perkawinan.

Di sinilah perlunya peran hakim dalam menilai pengajuan perkara itsbat nikah poligami, hakim harus membuat interpretasi yang arif, apakah perkara tersebut diajukan dari awal perkara izin poligami, atau perkara itsbat nikah istri poligami. Di satu sisi banyak penyelundupan perkara dengan mengajukan perkara itsbat nikah dengan tanpa melibatkan istri terdahulu padahal sebenarnya pernikahannya poligami. Di sisi lain perlu adanya wawasan hakim untuk memperhatikan nasib anak-anak yang dilahirkan dari perkawinan siri atau tidak dicatatkan, satu-satunya jalan dengan menempuh itsbat nikah di pengadilan agama sebagai solusinya. Hakim bebas untuk memberikan pertimbangan yang pada akhirnya menolak atau mengabulkan perkara yang diajukan ke pengadilan agama.
Pada akhirnya kembali kepada maksud dan tujuan perlunya suatu perkawinan dicatatkan adalah untuk mewujudkan ketertiban perkawinan dalam masyarakat. Ini merupakan suatu upaya yang diwujudkan perundangundangan untuk melindungi martabat dan kesucian perkawinan, lebih khusus lagi untuk melindungi hak-hak perempuan dalam kehidupan berumah tangga ${ }^{16}$.

Beberapa pertimbangan yang digunakan oleh para hakim dalam memerima perkara itsbat nikah antara lain:

1) Ketentuan dalam pasal 7 huruf (e) Kompilasi Hukum Islam "Perkawinan yang dilakukan oleh mereka yang tidak mempunyai halangan perkawinan menurut Undang- undang No.1 Tahun 1974”, dipahami sebagai perkawinan yang berlangsung baik sebelum maupun sesudah berlakunya undang-undang No.1 Tahun 1974 yang tidak mengandung unsur unsur yang

${ }^{16}$ Huzaimah Tahido Yanggo, Perkawinan Yang Tidak Dicatat Pemerintah (Jakarta; GTZ dan GG PAS, Mei 2007). h.17. 
menyimpang dan melanggar halangan-halangan perkawinan.

2) Hampir semua perkara itsbat nikah di pengadilan agama bagi perkawinan yang dilangsungkan sesudah Undang-undang No.1 Tahun 1974 berlaku, karena perkawinan yang tidak tercatat. "Tidak tercatat atau tidak dicatat" tidak sama dengan "tidak dicatatkan", istilah yang pertama tidak mengandung unsur "dengan sengaja" yang mengiringi itikad atau niat seseorang untuk tidak mencatatkan perkawinanya, sedang istilah yang kedua terkandung itikad atau niat buruk khususnya dari suami yang dengan sengaja tidak mencatatkan dengan maksud menyembuyikan perkawinannya, sebab hakim juga harus cermat dan hati-hati terhadap adanya upaya penyelundupan hukum dan poligami tanpa prosedur melalui permohonan Itsbat Nikah. Oleh karena itu terhadap kasus yang pertama, para hakim biasanya masih mengabulkan sepanjang syarat dan rukun nikah secara syar'i masih terpenuhi, ditambah dengan pertimbangan sosio kultural, ekonomi masyarakat setempat, dan apabila dalam proses pemeriksaan terindikasi ada upaya penyelundupan hukum, maka hakim akan menolaknya;

3) Memahami tentang fungsi pencatatan sebagai fungsi administratif yang disamakan dengan pencatatan peristiwa penting, bukan merupakan syarat sahnya perkawinan, maka sebenarnya sepanjang dalam pemeriksaan tidak terbukti ada syarat dan rukun perkawinan yang tidak dipenuhi, maka bagi mereka yang perkawinannya tidak dicatat berhak memperoleh pengesahan. Walaupun demikian terhadap permohonan itsbat nikah yang diajukan secara voulentir, kebanyakan hakim masih mensyaratkan adanya kepentingan hukum; Pendapat ini didasarkan kepada pendapat Prof. Bagir Manan bahwa akta nikah dan pencatatan perkwinan bukan satusatunya alat bukti mengenai adanya perkawinan atau keabsahan perkawinan. Fungsi dan 
kedudukan pencatatan perkawinan adalah untuk menjamin ketertiban hukum yang berfungsi sebagai instrumen kepastian hukum, kemudahan hukum, disamping sebagai salah satu bukti perkawinan, oleh karena itu jika terjadi pasangan yang telah melakukan perkawinan yang sah menurut agama, karena itu telah sah pula menurut pasal 2 ayat (1), tetapi belum dicatat, maka cukup dilakukan pencatatan. Jika pasangan itu diharuskan melakukan akad nikah lagi maka hal itu bertentangan dengan pasal 2 ayat (1), akibatnya perkawinan yang baru menjadi tidak sah ${ }^{17}$.

setelah penetapan itsbat nikah dilakukan oleh pengadilan agama, maka pemohon dapat mengajukan ke KUA setempat untuk mendapatkan kutipan akta nikah. Melalui pencatatan perkawinan yang dibuktikan dengan akta nikah, maka suami istri apabila dikemudian hari terjadi perselisihan atau salah satu pihak melalaikan kewajibannya, maka pihak lain dapat

${ }^{17}$ Bagir Manan yang dikutip oleh Neng Djubaidah, dalam bukunya yang berjudul Pencatatan Perkawinan dan Perkawinan Tidak Tercatat (t.cet; t. t: t. p, 2010). h .159 melakukan upaya hukum untuk memperoleh dan mempertahankan haknya masing-masing.

Para pelaku nikah siri atau nikah di bawah tangan, baik itu yang terjadi sebelum berlakunya Undangundang No. 1 tahun 1974 tentang perkawinan, maupun setelah berlakunya Undang-undang tersebut, tidak memiliki buku nikah/ akta nikah, yang pada akhirnya akan menimbulkan masalah dalam kehidupannya. Hal itu disebabkan karena mereka tidak bisa memperoleh kepastian hukum. Seperti untuk memperoleh akta kelahiran anak, mengurus keterangan pensiun, mengurus paspor, berangkat haji, dan lain sebagainya. Sekarang ini dapat di atasi dengan mengajukan istbat nikah ke pengadilan agama.

Setelah istbat nikah disahkan oleh hakim pengadilan agama, maka anak-anak yang lahir dari pernikahan siri dapat memiliki kekuatan hukum, anak juga memiliki hak memperoleh pelayanan administrasi kependudukan, seperti akta kelahiran. Selain itu tentu saja hak hukumnya sebagai ahli waris dari orang tuanya juga terjamin, atau pada pokoknya suami istri maupun 
anaknya mendapatkan perlindungan oleh mereka yang tidak mempunyai hukum setelah istbat nikah. halangan perkawinan menurut Pengadilan agama yang Undang-Undang No.1 Tahun 1974 mengabulkan permohonan itsbat nikah dapat diajukan itsbat nikah. pasca berlakunya Undang-Undang No.

Dalam mengajukan itsbat nikah 1 Tahun 1974, berarti melegitimasi dan ke Pengadilan Agama, pemohon harus mengakui perkawinan yang yang tidak memiliki alasan-alasan sebagai dicatat. Di samping itu, secara persyaratan diterimanya permohonan sosiologis itsbat nikah terhadapat itsbat nikah tersebut. Kompilasi perkawinan yang dilakukan setelah Hukum Islam telah mengaturnya berlakunya Undang-Undang No. 1 sebagaimana diatur dalam pasal 7 Tahun 1974, dapat menyuburkan antara lain; dalam rangka penyelesaian praktek nikah siri di masyarakat karena perceraian, hilangnya akta nikah, perkawinan yang tidak dicatatkan adanya keraguan tentang sah atau (nikah siri) itu dapat diitsbatkan oleh tidaknya salah satu syarat perkawinan, pengadilan agama.

\section{Simpulan}

Pada dasarnya setiap perkawinan baik itu yang terjadi sebelum berlakunya Undang-undang Nomor 1 tahun 1974 tentang perkawinan maupun setelah berlakunya Undangundang perkawinan tersebut, asalkan pernikahan tersebut telah memenuhi rukun dan syarat perkawinan, serta dilangsungkan berdasarkan ketentuan agama Islam (bagi yang menganut agama Islam). Hal itu diatur dalam Kompilasi Hukum Islam pasal 7 huruf adanya perkawinan yang terjadi sebelum berlakunya Undang-Undang No. 1 Tahun 1974, dan perkawinan yang dilakukan oleh mereka yang tidak mempunyai halangan perkawinan menurut Undang-Undang No. 1 Tahun 1974.

Pertimbangan hakim dalam mengabulkan permohonan itsbat nikah; antara lain adalah, adanya perkawinan yang terjadi sebelum berlakunya Undang-Undang Nomor 1 tahun 1974 tentang perkawinan, telah terpenuhi rukun dan syarat perkawinan e, yaitu perkawinan yang dilakukan sebagaimana yang termuat dalam pasal 
14 sampai dengan pasal 30 Kompilasi Hukum Islam, begitu juga dengan Undang-Undang Nomor 1 Tahun 1974 tentang perkawinan. Dalam hal mengabulkan permohonan yang terjadi setelah berlakunya undang-undang perkawinan, maka yang menjadi dasar pertimbangan hakim adalah asas kemanfaatan, terpenuhinya rukun dan syarat perkawinan, dan orang yang telah melangsungkan perkawinan bukan termasuk mereka yang tidak mempunyai halangan perkawinan menurut Undang-Undang Nomor 1 Tahun 1974 tentang perkawinan.

\section{Daftar Pustaka}

Abdullah, Gani Abdul, Sekitar masalah pengesaban Nikah Siri, Materi Rakernas Perdata Agama Mahkamah Agung RI, Jakarta, 2008.

Abdurrahman, Kompilasi Hukum Islam di Indonesia, Cet.III; Jakarta: Akademi Pressindo, 2001.

Amalia, Rizky. Itsbat nikah Terbadap Perkawinan yang Dilangsungkan Sebelum dan Sesudab Berlakunya UU No. 1 Tabun 1974 Tentang
Perkawinan (Studi Kasus

Penetapan PA Jakarta Selatan dan PA Depok), Tesis, Universitas Indonesia, Jakarta: 2012.

Djubaidah, Neng. Pencatatan Perkawinan dan Perkawinan Tidak Tercatat, t.cet; t. t: t. p, 2010.

http://badilag.net/artikel/12647-

nikah-sirri-vs-itsbat-nikah-

oleh-drs-h-abd-rasyid-asad-

mh-259.html, diakses pada tanggal 25 Februari 2017.

M. Zein, Satria Efendi. Problematika Hukum Keluarga Islam Kontemporer, Analisis dengan Pendekatan Ushuliyah, Cet. I; Jakarta: Prenada Media, 2004.

Mahkamah Agung RI, Pedoman Teknis Administrasi dan Pedoman Teknik Peradilan Agama, Buku II Edisi 2009.

Mahkamah Agung RI, Pedoman Teknis Administrasi dan Pedoman Teknik Peradilan Agama, Buku II Edisi 2009.

Manan, Abdul. Aneka Masalah Hukum Perdata Islam di Indonesia, Jakarta: Kencana, 2006 
Muhsin, Problematika Perkawinan tidak tercatat dalam pandangan Hukum Islam dan Hukum Positif, Materi Rakernas Perdata Agama.

Salim, Nasrudin. Itsbat nikeab dalam Kompilasi Hukum Islam, Mimbar Hukum No. 62 tahun 2003 Edisi SeptemberOktober.

Syamsu, Alam H.Andi (Tuada Uldilag), Beberapa permasalahan Hukum di Lingkungan Uldilag (Hasil Rapat Kerja Nasional Mahkamah Agung RI, Tahun 2009.

UU No.1 Tahun 1974 tentang Perkawinan

Wawancara dengan Bambang Suroso SH ( Panitera Muda Hukum), pada tanggal 17 Juli 2013 pukul 10.00 wita di Pengadilan Agama Manado

Yanggo,Tahido Huzaimah. Perkawinan Yang Tidak Dicatat Pemerintah, Jakarta; GTZ dan GG PAS, Mei 2007. 